\title{
Borrowed Words in English and Chinese Vocabulary
}

\author{
Yingying Shen \\ Center for Lexicographical Studies \\ Guangdong University of Foreign Studies \\ Guang Zhou 510420, China \\ E-mail: selena121212@yahoo.com.cn
}

\begin{abstract}
Borrowed words are the products of language development and cultural contact. This paper probes into the brief study of borrowed words in both English and Chinese vocabulary. At the very beginning it generally introduces issues being covered, and the following two parts center on the study of borrowed words on the basis of dictionary research. Later, this paper figures out the significance of borrowed words study for EFL (English as Foreign Language) learners, particularly those Chinese ones, and gives some advice for borrowed words learning.
\end{abstract}

Keywords: Borrowed words, Vocabulary, Significance

\section{Introduction}

Language, both an important tool in human communication and a significant reflection of social development, undergoes rapid changes during the histories. As Sapir puts, "Languages, like cultures, are rarely sufficient unto themselves. The necessities of intercourse bring the speakers of one language into direct or indirect contact with those of neighboring or culturally dominant languages."(Sapir, 2001:159) Therefore, the result of continuous contact between different speaking communities is that people use each other's words to refer to some particular things, process, or ways of thinking. This kind of using others' languages is called borrowing, which is a natural result of language contact and exerts a profound impact on both vocabulary enrichment and mutual understanding of cultures.

Borrowing can go in both directions between the two languages in contact, such as English and Chinese. More and more linguists attach importance to and research on the borrowed words (i.e. words produced in the process of borrowing) in both English and Chinese vocabularies, while few of them relate borrowed words to its significance for English as Foreign Language (EFL) Learners, especially those Chinese ones. This paper tries to do a better job on this point and give some advice for borrowed words learning.

\section{Chinese Borrowed Words in English Vocabulary}

\subsection{Brief History of English Words Borrowed From others}

English is an open language and "in its development has managed to widen her vocabulary by BORROWING words from other languages". (Hu, 2004) It adopted a vast number of words from various languages during different periods of time, which can be viewed as follows: I. Germanic period (AD200-400): in this period, words were mainly borrowed from Latin. II. Old English Period (AD600-1100): Latin and Celtic were major borrowed words in this period and thousands of place and river names were given at that time. III. Middle English Period (AD1100-1500): Scandinavian became one of major borrowed words in the early period and later French influenced significantly in many aspects of English society, including politics, economy, and religion. IV. Early Modern English Period (AD1500-1650): The effects of the renaissance began to be seriously felt in England. There is a huge influx of Latin and Greek words, but many are borrowings from other languages, such as Arabic. V. Modern English (AD1650-present): great changes occur in the world during this period: major colonial expansion, industrial and technological revolution, immigration, cultural contact and exchange, etc. Major borrowed words in English vocabulary come from French, Spanish, Italian, Dutch, Flemish German....and, Chinese.

\subsection{Studies on Chinese Borrowed Words}

The KryssTal Web Site is a United Kingdom based educational and information web site by Kryss Katsiavriades and Talaat Qureshi in London. On this web site, we can click on any of interested fields related to our research. In order to find out examples of Chinese borrowed words in English language, we can click on the label of "borrowed words in English" and a picture comes out as in figure 1. 


\section{Insert Figure 1 Here}

When letter "C" (which stands for "Chinese") is clicked on, a portion of Chinese borrowed words in English vocabulary can be found as in table 1 .

\section{Insert Table 1 Here}

In order to study Chinese borrowed words in English vocabulary based on dictionary research, Vice Professor Zeng Tai Yuan of Dong Wu University, Taiwan, gave a close look to Shorter Oxford English Dictionary (Fifth Edition) and found out that there were at least about 300 words in English vocabulary borrowed from Chinese. (Zeng, 2005) He classified these borrowed words into 23 categories and gave a clear list of them in his paper. Later in 2007, he studied on Webster's Third New International Dictionary and found out about 543 Chinese borrowed words were included in this dictionary. He also divided them into 23 types and figure out the majority of them are those words used in the field of places and minorities, plants, and food.

Similarly, this paper has done a research on Longman Dictionary of Contemporary English (electronic edition) and finds out 24 borrowed words with Chinese origin, 2 with Cantonese origin, and 2 with Mandarin Chinese origin.

Insert Table 2 Here.

It is not difficult for us to understand that LDOCE4, as a dictionary mainly for learners, can only include some of the Chinese borrowed words (28) but not most of them like in Shorter Oxford English Dictionary (300) and Webster's Third New International Dictionary (543). However, there are a few mistakes made by the compilers of LDOCE4. First, we can see in this form that "chow", a Chinese borrowed word, belongs to both Cantonese origin and Mandarin Chinese origin. As we know, Cantonese is a famous dialect spoken in Guangdong province and Hong Kong, and its pronunciation is not the same as Mandarin, although two of them are written in the same Chinese characters. Thus, it is impossible for one word belong to both Cantonese and Mandarin at the same time. Second, it is a little difficult to understand why the compilers of LDOCE4 have to divide Chinese borrowed words into three categories: Chinese origin, Cantonese origin and Mandarin Chinese origin. As a matter of fact, all of these three categories belong to Chinese language, and it is unnecessary to separate them.

A more reasonable classification of Chinese borrowed words in English vocabulary is presented by Zou Yuanyan, whose paper provides brief history of the Chinese borrowed words in English and classifies them into four kinds: English words borrowed from Mandarin, from Cantonese, and from Amoy (another Chinese dialect spoken in southern Fujian province and Tai Wan). (Zou, 2006)

Nevertheless, all of our study and discussion mentioned in this part lead us to the conclusion that numbers of Chinese borrowed words do exist in English vocabulary and play an important role in cultural contact. They not only enrich the English vocabulary but also draw more and more western people's attention to know China in every aspect of life, such as Chinese food, clothes, plants, places, traditional medicine, and so on.

\section{English Borrowed Words in Chinese Vocabulary}

Similarly as English borrowed lots of words from Chinese, there are many English borrowed words in Chinese vocabulary concerning every aspect of social life. According to a stratified sampling researched by Zhang Peng in his MA degree thesis, examples of English borrowed words are divided into 14 groups: a. Politics; b. Arts and Literature; c. Philosophy; d. economics; e. Mathematics, Physics, and Chemistry; f. Society, Culture, Education, Publication and Sports; g. Religion; h. Law; i. Military Science; j. Botany and Biology; k. Psychology, Physiology, Geology, and Geography; 1. Building, Machinery, and Communication; m. Textile, Clothing, and Daily Necessities; n. Language, Foreign Affairs, and Others. (Zhang, 2005:10-15)

Based on his samples and other corpus collected from real life, this paper would like to classify Chinese borrowed words as in table 3:

Insert Table 3 Here

Examples above show that Chinese language have been greatly influenced by western languages, especially English, and meanwhile witnessed rapid changes in every aspect of social life including politics, economics, military, food, clothing, ... and so on. According to Deng (Deng, 2005), the percentage of borrowed words in Chinese neologisms is much bigger than that in English neologisms, and it is pointed out by Tian that "with the increasing frequency of the language contact of Chinese with other languages, it is believed that more words will be borrowed into Chinese like English". (Tian, 2007:63)

To study English borrowed words in Chinese vocabulary based on dictionary research, this paper finds out that there are 142 "acronyms and words beginning with Greek or Latin letters" in the back matters of The Contemporary Chinese Dictionary (Chinese-English edition, 2002) and most of them are English borrowed words such as e-mail, CT, CPU, DOS, DVD, FAX, internet, and so on. What's more, this paper takes Dictionary of Loanwords in Chinese (a dictionary 
which contains more than 10,000 Chinese borrowed words from different languages such as Latin, French...etc.) as a sample and investigates all the Chinese words in the dictionary initiated with Pin Yin "a". Finally the result shows that in the total number (543) of loanwords beginning with "a", 230 are borrowed from English. It can be estimated generally that about $42.357 \%$ of borrowed words in Chinese vocabulary are English ones. That is to say, there are more than 4200 English borrowed words in Chinese vocabulary. - A huge number we cannot ignore. Examples can be seen as in figure 2.

Insert Figure 2 Here.

\section{Significance of Borrowed Words for EFL Learners}

Table 4 illustrates the proportion of total borrowed words in both English and Chinese vocabulary:

Insert Table 4 Here

This table shows that in the process of social contact and exchange, English and Chinese inevitably import a huge number of languages from other languages. Therefore, Chinese EFL learners have to encounter all the difficulties and challenges and learn borrowed words to meet the time's need. Chinese borrowed words in English and English ones in Chinese are of great significance for learners in the following aspects:

1) Vocabulary building: Undoubtedly, learning borrowed words can widen Chinese EFL learners' vocabulary and help them to improve their English proficiency. Borrowed words can be stored as culture-specific dictionary in their mental lexicon, and they can understand them when reading and use them when writing.

2) Interests in study: Borrowed words usually seem fashionable and interesting, which can attract Chinese young students deeply and stir up their enthusiasm and motivation in learning English.

3) Attitude towards Chinese culture: Borrowed words in English and Chinese vocabulary express that all the cultures and nations are equal in the process of development and contact, which reminds Chinese EFL learners not to ignore the importance of Chinese culture or language when learning foreign languages and to set up positive attitude towards both national and international cultural products.

4) Understanding of foreign culture: Meanwhile, borrowed words can help Chinese EFL learners gain a better and deeper understanding about foreign cultures, politics, economics, religion... etc., which will influence their values of life.

5) Communicating ability: Borrowed words learning has become a matter of practical necessity and enables Chinese EFL learners to communicate effectively with foreign language speakers, especially those English speakers. Without borrowed words learning, misunderstanding and mistake will occur and further conversation will be impossible.

6) Translating skill: It is not difficult to understand the importance of borrowed words learning when Chinese EFL learners translate Chinese into English or English into Chinese. Hu has stated four types of processes with regard to borrowing: loanwords, loan blend, loan shift, and loan translation. (Hu, 2004:102) Borrowed words are produced by means of loan translation and will in turn affect the translation of words such as culture-specific words or neologisms.

In addition, here are pieces of advice given to Chinese EFL learners for borrowed words learning:

1) Read more and collect more: Read more books, including textbooks, magazines, newspapers, books in the library, etc., and collect borrowed words in notebooks when reading.

2) Make use of information through all ways in life: Make full use of different information through all ways in life, such as watching television, listening to the radio, and surfing on line, to learn borrowed words and develop a good habit of learning.

3) Find out the root and rule: When face unknown words that may be borrowed ones, find out the root and origin of them in order to get a full understanding and after a period of accumulation, try to find out the rules of formation for the sake of easier further learning.

\section{Conclusion}

To sum up, borrowed words are a crucial part in the area of social contact, linguistic research, and vocabulary study. Findings and inadequacies of this paper can be seen as follows:

First, based on concerned website or dictionary research, numbers and categories of Chinese borrowed words in English vocabulary can be known and discussed. It is easier for linguists to do research concerned than ever before because of the development of computing technology and electronic English dictionaries.

Second, numbers and categories of English borrowed words in Chinese vocabulary can be estimated but it is much more difficult for researchers to calculate exactly and discuss fully on this field due to the lack of electronic Chinese dictionaries. 
Third, English borrowed words in Chinese vocabulary greatly outnumber Chinese ones in English.

Last but not least, borrowed words learning are of great importance to Chinese EFL learners, but the significance covered in this paper is not adequate and profound enough, further discussion and exploration will be needed.

\section{Dictionaries used:}

Longman Dictionary of Contemporary English UPDATED EDITION (CD-ROM $4^{\text {th }}$ edition) Longman Group UK Ltd 2004.

The Contemporary Chinese Dictionary (Chinese-English edition) Foreign Language Teaching and Research Press 2002.

Liu Zhengtan et al. eds. Hanyu Wailaici Cidian. (Dictionary of Loanwords in Chinese). Hong Kong: Commercial Press; Shanghai: Shanghai cishu chubanshe. 1985.

\section{References}

Deng Zhongtian. (2005). On the Chinese and English Cultural Similarities and Differences from the Perspective of Neologism. Teaching and research Chinese as a foreign language. 6, 62.

Hu Zhuang lin. Linguistics. (2001). A Course Book (Second Edition). Beijing: Beijing University Press, 101.

Sapir, E. (2001). Language: An Introduction to the Study of Speech. Beijing: Foreign Language Teaching and Research Press.

Tian lili. (2007). A Comparative Study of Loanwords in English and Chinese in the Perspective of Language Contact. MA Dissertation, Central South University.

Zeng Taiyuan. (2005). Cong niu jin ying yu ci dian jian bian di wu ban kan han yu wen hua te se ci ying yi fang xiang (Translating Chinese Culture-Specific Words into English - from a Perspective of Shorter Oxford English Dictionary $5^{\text {th }}$ edition). Journal of Guangdong University of Foreign Studies. B11, 74-77.

Zhang Peng. (2005). Study on English Loan Words in Chinese. MA Dissertation, Tianjin University of Finance \& Economics, 10-15.

Zou Yuanyan. (2006). On Chinese Loanwords in English. Journal of Chongqing Vocational \& Technical Institute, 5, 98-99.

Table 1. Words borrowed from Chinese

\begin{tabular}{|l|l|l|}
\hline Word & Meaning & Notes \\
\hline char & tea & Used in UK slang as in "a cup of char". \\
\hline China & middle country & Asian country. Also used for porcelain in UK. \\
\hline ginseng & image of man & Root of medicinal plant which is forked. \\
\hline Japan & rising sun & Asian country. \\
\hline kowtow & bump head & Showing respect. \\
\hline kung fu & merit master & A martial art. \\
\hline sampan & three sails & A three sailed boat. \\
\hline shanghai & on the sea & In the old days men would be "shanghaied" - forced to serve in the navy. \\
\hline tofu & spoilt bean & A soya bean extract. From "dou fu". \\
\hline typhoon & big wind & Violent Asian storm. The Atlantic Ocean version is called a "hurricane". \\
\hline yin and yang & & Opposite characteristics. \\
\hline
\end{tabular}

Table 2. Chinese borrowed words in LDOCE4

\begin{tabular}{|c|c|c|c|}
\hline $\begin{array}{l}\text { Chinese origin (24): } \\
\text { bok choy, noun; } \\
\text { kimchi, noun; } \\
\text { lychee, noun; } \\
\text { sampan, noun; } \\
\text { tea, noun; } \\
\text { yang, noun; }\end{array}$ & $\begin{array}{l}\text { feng shui }{ }^{1} \text {, noun; } \\
\text { kowtow, verb; } \\
\text { mahjong, noun; } \\
\text { Shinto, noun; } \\
\text { tycoon, noun; } \\
\text { yen, noun; }\end{array}$ & $\begin{array}{l}\text { ginseng, noun; } \\
\text { kumquat, noun; } \\
\text { pak choi, noun; } \\
\text { soya, noun; } \\
\text { typhoon, noun; } \\
\text { yin, noun; }\end{array}$ & $\begin{array}{c}\text { gung-ho, adjective } \\
\text { kung fu, noun } \\
\text { pidgin, noun } \\
\text { Tao, noun } \\
\text { wok, noun } \\
\text { yuan, noun }\end{array}$ \\
\hline $\begin{array}{l}\text { Cantonese origin (2) } \\
\text { chop suey, noun; }\end{array}$ & chow ${ }^{1}$, noun & & \\
\hline $\begin{array}{l}\text { Mandarin Chinese or } \\
\text { chow }{ }^{1} \text {, noun; }\end{array}$ & $\begin{array}{l}\text { rigin (2): } \\
\text { chow mein, noun }\end{array}$ & & \\
\hline
\end{tabular}


Table 3. Borrowed words in Chinese language

\begin{tabular}{|c|c|}
\hline Politics & $\begin{array}{l}\text { leng zhan (cold war), tang ning jie (downing street), fei bian she (Fabian } \\
\text { Society), wu tuo bang (Utopia) }\end{array}$ \\
\hline Economics & $\begin{array}{l}\text { yin hang (bank), zhi pian (check), hua'er jie (Wall Street), ka te'er (cartel), } \\
\text { xiong shi (Bear market), niu shi (Bull market) }\end{array}$ \\
\hline Military & $\begin{array}{l}\text { tan ke (tank), bo lang ning (browning), ge lin pao (Gatling gun), ka bing qiang } \\
\text { (carbine) }\end{array}$ \\
\hline Religion & $\begin{array}{l}\text { a men (amen), an qi'er (angel), ye he hua (Jehovah), yi dian yuan (Eden } \\
\text { garden), mi sa shu (missal), mu nai yi (Mummy), mu si lin (Moslem), gu lan } \\
\text { jing (Koran), sa dan (Satan) }\end{array}$ \\
\hline Food & $\begin{array}{l}\text { lv se shi pin (green food), ken de ji (Kentucky), mai dang lao (McDonald's), zi } \\
\text { zhu can (buffet), nai xi (milkshake), re gou (hot dog), sha ding yu (sardine), xi } \\
\text { leng niu pai (sirloin steak), zha pi (a jar of beer), xue bi (Sprite), ke kou ke le } \\
\text { (Coca-Cola), bai shi ke le (Pepsi-cola), ruan yin liao (soft drink), bai lan di } \\
\text { (brandy), wei shi ji (whiskey), sha la (salad), bu ding (pudding), qiao ke li } \\
\text { (chocolate), san ming zhi (sandwich) }\end{array}$ \\
\hline Clothing & $\begin{array}{l}\text { niu zi ku (jeans), mi ni qun (miniskirt), bi ji ni (bikini), ni long (nylon ), } \mathrm{T} x \mathrm{xu} \\
\text { shan ( } \mathrm{T} \text {-shirt) }\end{array}$ \\
\hline Daily life & $\begin{array}{l}\text { sang na yu (sauna), tai yang yu (suntan), shi duo dian (store), xiang bo } \\
\text { (shampoo), xi meng si (shermons), ma sai ke (mosaic), te fu long (teflon), xue } \\
\text { jia (cigar), sha fa (sofa) }\end{array}$ \\
\hline $\begin{array}{l}\text { Art, } \\
\text { Entertainment, } \\
\text { Sport }\end{array}$ & $\begin{array}{l}\text { jue shi yue (jazz music), fei zao ju (soap opera), mi huan yao gun yue (acid } \\
\text { rock), jue shi yao gun (jazz rock), di si ke (disco), pi li wu (break dance), yao } \\
\text { gun yue (rock and roll), ba lei wu (ballet), hua'er zi wu (waltz), sang ba } \\
\text { (samba), tan ge (tango), pai dui (party), MTV (music television), di si ni le } \\
\text { yuan (Disney land), liu liu qiu (yo-yo), hu la quan (hula-hoop), bao ling qiu } \\
\text { (bowling), gao'er fu qiu (golf), la li sai (rally), ka ding che (karting), beng ji } \\
\text { tiao (bunge jumping), ma la song (marathon), ao yun hui (Olympic Games) }\end{array}$ \\
\hline Value of life & $\begin{array}{l}\text { dai gou (generation gap), wen hua cha ju (culture gap), dan shen mu qin } \\
\text { (bachelor mother), ying zhao nv lang (call girl), xi pi shi (Hippies), ya pi shi } \\
\text { (Yuppies), yin pi shi (Yumpies), peng ke (punk) }\end{array}$ \\
\hline Social position & $\begin{array}{l}\text { bai ling (white collar), lan ling (blue collar), hui ling (gray collar), fen ling } \\
\text { (pink collar), tie ling (iron collar) }\end{array}$ \\
\hline $\begin{array}{l}\text { Science and } \\
\text { Technology }\end{array}$ & $\begin{array}{l}\text { gao ke ji yuan (hi-tech park), gui gu (silicon valley), chuan zhen (fax), ji } \\
\text { guang da yin ji (laser printer), dian shi dian hua (videophone), DNA, shi guan } \\
\text { ying'er (test-tube baby), ke long (clone), PPS (pocket phone service), CD } \\
\text { (compact disc), VCD (video-compact disc), DVD (digital video/ versatile } \\
\text { disc), VTR (video tape recorder), VCR (video cassette recorder), jia ting lu } \\
\text { xiang (family video) }\end{array}$ \\
\hline $\begin{array}{l}\text { Computer and } \\
\text { Website }\end{array}$ & $\begin{array}{l}\text { ying jian (hardware), ruan jian (soft ware), shu ju ku (data bank), dian zi you } \\
\text { jian (E-mail), yin te wang (internet), Windows } 98 \text {, shu biao (mouse), dui hua } \\
\text { kuang (dialog box), chao wen ben (hypertext), CAI (computer-assisted } \\
\text { instruction), wang luo ren (cybernaut), wang luo chong lang zhe (cybersurfer), } \\
\text { wang mi (cyber mania), wang ba (cyber bar) }\end{array}$ \\
\hline Transportation & $\begin{array}{l}\text { ba shi (bus), di shi (taxi), mo tuo che (motorcycle), ji pu che (jeep), qi lun ji } \\
\text { lie che (turbo train), kong zhong ke che (airbus), ATV (air-terrain vehicle) }\end{array}$ \\
\hline $\begin{array}{l}\text { Health } \\
\text { Medicine }\end{array}$ & $\begin{array}{l}\text { wei ta ming (vitamin), he'er meng (hormone), ma fei (morphine), ya pian } \\
\text { (opium), a si pi lin ( aspirin), pan ni xi lin (penicillin), ai zi bing (AIDS), liu } \\
\text { xing bing (epidemic), SARS, fan shi lin (Vaseline), ka lu li (calorie), ni gu } \\
\text { ding (nicotine), dian (iodine) }\end{array}$ \\
\hline
\end{tabular}


Table 4. Borrowed words in English and Chinese (Tian, 2007:52)

\begin{tabular}{|c|c|c|c|}
\hline Language & Vocabulary & Loanwords & Percentage \\
\hline English & $1,000,000$ & 500,000 & $50 \%$ \\
\hline Chinese & 70,000 & 10,000 & $14 \%$ \\
\hline
\end{tabular}

\section{The English Language}

Words Borrowed from Other Languages

\section{Hundreds of words from 146 languages}

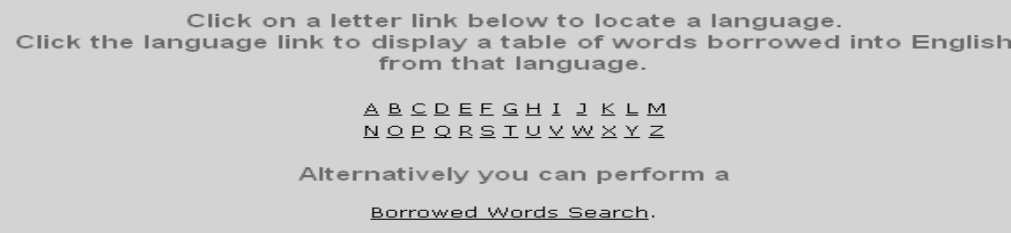

Figure 1. Borrowed words in English language

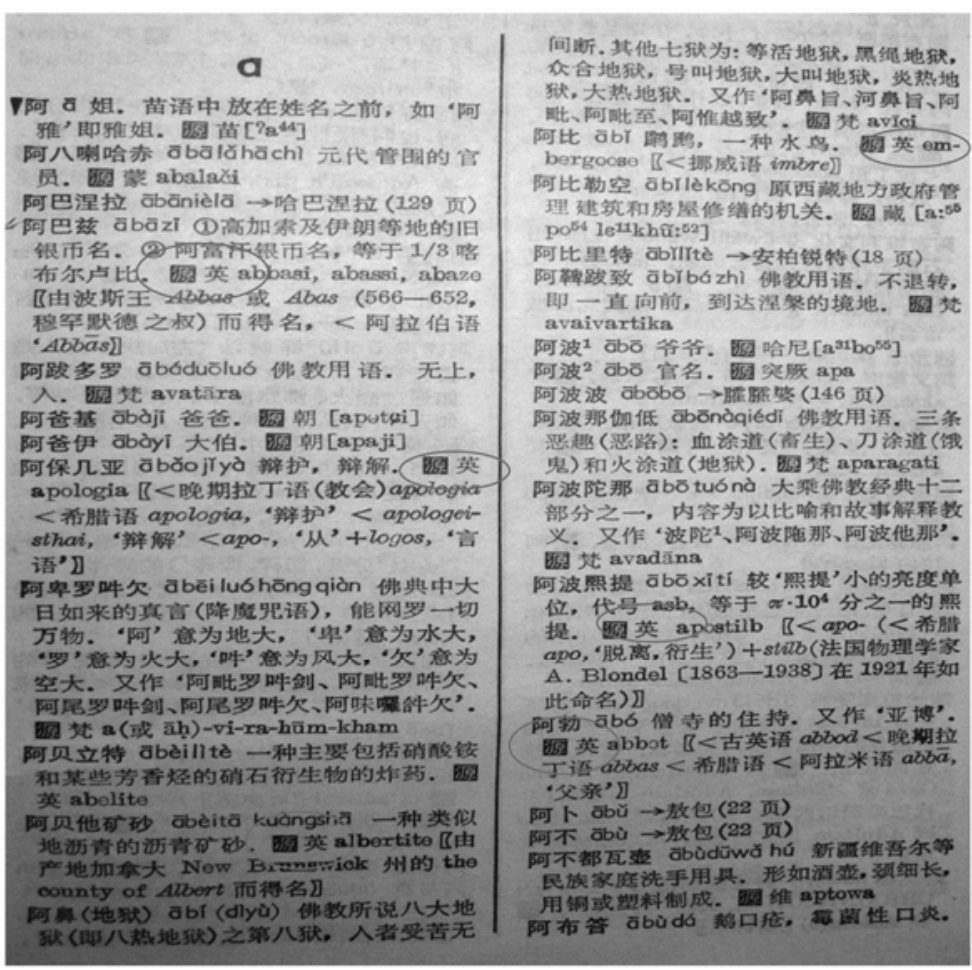

Figure 2. Sample collected from Dictionary of Loanwords in Chinese 